TEME, г. XLV, бр. 1, јануар - март 2021, стр. 349-366

\begin{tabular}{lr}
\hline \hline Претходно саопштење & https://doi.org/10.22190/TEME200210019C \\
Примљено: 10. 2. 2020. & UDK 339.5:631(497.11) \\
Ревидирана верзија: 24. 5. 2020. & \\
Одобрено за штампу: 26. 2. 2021. &
\end{tabular}

\title{
AGRICULTURAL INTRA-INDUSTRY TRADE IN SERBIA
}

\author{
Đorđe Ć uzović ${ }^{1 *}$, Svetlana Sokolov-Mladenović ${ }^{2}$ \\ ${ }^{1}$ Novi Sad School of Business, Novi Sad, Serbia \\ ${ }^{2}$ University of Niš, Faculty of Economics, Niš, Serbia
}

\begin{abstract}
Intra-industrial trade is the exchange of products between countries in the same sector of the economy. A significant part of export and import in goods takes place within the same sector of the economy. This paper analyzes the intra-industrial trade in agricultural products of Serbia and its foreign trade partners from 2004 to 2018. The Grubel-Lloyd intra-industrial trade index was used as a measure. The value of GLI in agricultural products increased over the observed period, ranging from 0.485 to 0.590 as in 2018 , while the number of IIT-dominated groups ranged from 26 to 35 . The results obtained indicate that vertical IIT is more prevalent than horizontal IIT and that the export of products with lower prices dominates, i. e. those that are, according to the assumptions of the model, of lower quality than the imported products. Dynamic change analysis shows that certain changes in the IIT pattern occur over time, but that changes are gradual without sudden peaks in the IIT structure.
\end{abstract}

Key words: intra-industrial trade, Grubel-Lloyd index, agriculture, Serbia, international trade.

\section{ИНТРАИНДУСТРИЈСКА ТРГОВИНА ПОЉОПРИВРЕДНИМ ПРОИЗВОДИМА У СРБИЈИ}

\section{Апстракт}

Интраиндустријска трговина представља размену производа истог сектора привреде између земаља. Значајан део извоза и увоза производа одвија се унутар истог сектора привреде. У раду је анализирана интраиндустријска трговина пољопривредним и прехрамбеним производима Србије и њених спољнотрговинских партнера у периоду од 2004. до 2018. године. За мерење је коришћен Грубел-Лојдов (Grubel-Lloyd) индекс интраиндустријске трговине (GLI). Вредност GLI пољопривредних и прехрамбених производа расла је у посматраном периоду и кретала се од 0,485 до 0,590 , колико је износила 2018 . године, док се број група код којих је доминирала ИИТ кретао од 26 до 35. Добијени резулта-

\footnotetext{
* Аутор за кореспонденцију: Ђорђе Ћузовић, Висока пословна школа струковних студија, Владимира Перића Валтера 4, 21000 Нови Сад, Србија, cuzovic@ gmail.com
} 
ти указују на то да је вертикална ИИТ заступљенија од хоризонталне ИИТ и да доминира извоз производа који имају ниже цене, тј. који су према претпоставкама модела лошијег квалитета у односу на производе из увоза. Анализа динамичких промена показује да долази до одређених промена у обрасцу ИИТ током времена, али да се промене дешавају постепено, без наглих промена у структури ИИТ.

Кључне речи: интраиндустријска трговина, Грубел-Лојдов индекс, пољопривреда, Србија, међународна трговина.

\section{INTRODUCTION}

During the $20^{\text {th }}$ century, the pattern of trade changed significantly. Due to lower transportation costs, the liberalization of international trade and economic integrations, international trade flows were intensified. Along with the growth of product exchange in different sectors of the economy, there is also an increase in the exchange of products in the same sectors of the economy. The emergence of trade is related to the exchange of agricultural products (Ćuzović, 2009, p. 27). A number of theorists explain international trade using David Ricardo's logic and his theory of comparative advantages. According to this theory, countries should specialize in the production of goods where they have comparative advantages and then exchange these products on the international market. In literature, the Heckscher-Ohlin model emerged later, incorporating two factors of production, and it became the dominant model of inter-industrial trade. According to the Heckscher-Ohlin theory, in a trade exchange between two countries, the country with higher relative availability of capital will export capital-intensive products. However, after World War II, the pattern of trade changed, so that trade liberalization and integration of countries took place. Under such conditions, countries were increasing trade and beginning to simultaneously export and import the same products.

The first studies addressing intra-industrial trade (IIT) were conducted in the 1960s (Verdoorn, 1960; Balassa, 1966), and after that extensive literature analyzing the field was published. Much attention has been paid to the study of IIT, as it is in contrast to traditional theories of international trade. These authors have come to the revolutionary observation that there is a specialization within the industry as well as a two-way international trade in products within the industry (Lloyd \& Lee, 2002, p. 1).

One of the most common definitions of intra-industrial trade is that it represents the simultaneous export and import of similar products or services by the same country. Qasmi \& Fausti (1999, p. 256) emphasize that IIT is connected to monopolistic markets and that international competition compels companies in monopolistic markets to specialize and exploit economies of scale by narrowing their production lines. According to the same authors, information on trade patterns can assist agricultural producers in strategic planning. Intra-industrial trade implies an increase in cost- 
effectiveness, while information on the existence of IITs affects the specialization, differentiation and specific promotion of products.

In their work, Kol \& Tharakan (1989) reviewed previous research dealing with IIT and highlighted differences that occur between the authors due to empirical observation and expectations based on traditional trade theories. Their paper highlights two views that explain the differences between empirical data and theoretical assumptions. According to the first view, IIT is a consequence of the inclusion of different products in the same statistical category. This phenomenon is called "categorical aggregation" and according to this view the difference of factor content (factor intensity) of these products is large enough to explain the validity of the Heckscher-Ohlin theory. The second approach in explaining the IIT phenomenon starts with the removal (mitigation) of assumptions on which the Heckscher-Olin theory is based. The assumption of a constant-yield production process is replaced by a higher-yield production process, product differentiation is introduced, and perfectly competitive markets are replaced by imperfect ones. In this way, theoretical foundations and different models have been created to explain empirical data on IITs. According to this view, the inclusion of products of different factor-intensity in the same category in the classification (categorical aggregation) may be consistent with the presence of different types of IITs.

Grubel \& Lloyd (1975), whose index is most commonly used to measure IIT, categorized the products for which IIT was recorded. The first group consists of homogeneous products where exchange occurs due to transport costs and seasonal differences in production. The second group consists of heterogeneous products which may be substitutes. This group may include products that use different inputs and possibly represent direct substitutes, such as similar products obtained naturally or artificially, or products using the same inputs but intended for different end users (metals for the automotive and construction industries) and also products made from similar materials and using similar production processes (cars, television sets, etc.). The third group consists of heterogeneous products linked to the production stages in the same sector. This method of trading is called vertical trading and is present in sectors operated by transnational companies.

In a study conducted by Frankel (1943), the author concludes that countries that are open to international trade, that is, have a higher share of exchange per capita, more often export and import the same products, i.e. have a higher proportion of IITs (as cited in Kol \& Tharakan, 1989). He explained this phenomenon by the difference in product quality, which is the result of differences in workers' skills between countries.

In addition to industrial products, where IIT was first observed, IIT is becoming more common in agricultural products. According to the data of the Statistical Bureau of the Republic of Serbia, agriculture's share in GDP in 2018 was 7\%, while agricultural exports accounted for $18.3 \%$ of 
the value of total exports. The share of agricultural products import in the total import was $8.4 \%$ in the same year. In the period between 2004 and 2018, agricultural export averaged $21.7 \%$ of total export, while import averaged $7.9 \%$ of total import. The foreign trade balance in the exchange of the mentioned products was negative only in 2004, while the surplus has been recorded since 2005. Serbia's most important foreign trade partners in agricultural trade include the EU, CEFTA 2006 member states and the Russian Federation. Agricultural trade between Serbia and these three most important foreign trade partners accounted for $87.4 \%$ of total export and $74.7 \%$ of total agricultural import in 2018. The presented data indicate that Serbia exports and imports agricultural products, and this paper examined IIT for these products using the GL index of IIT.

A similar analysis was made by Hoang (2019), who analyzed the IIT in Vietnam agriculture between 1997 and 2014. The author points out that the pattern of IIT in agricultural products depends on local production and demand, and that the economies of developing and transition countries diversify trade activities and IIT due to the restructuring of the economy and the spread of globalization.

Horizontal and vertical IIT should be distinguished when analyzing IIT. Horizontal IIT is an exchange of similar products, of similar quality but with different characteristics. Vertical IIT is an exchange of similar products, but of different quality. It is often emphasized that vertical IIT is characteristic for the exchange between developed and developing countries, while horizontal one is characteristic for exchange between developed countries. Within the framework of economic integrations, a growth of vertical IIT occurs that includes similar products with different quality levels. These theoretical assumptions have been confirmed by available research. In a paper that analyzes the determinants of horizontal and vertical IIT in trade between countries of the Visegrad Group, Jámbor (2015) points out that agricultural products are dominated by vertical IIT, i.e. that products of different quality are being exchanged. In another paper, the same author states that after Hungary joined the EU their vertical IIT increased, that is, the exchange of products of different characteristics and prices (Jámbor, 2010). Similar results were obtained by Fertö (2015), who analyzed horizontal IIT in the EU from 1999 to 2010. His results show a low level of horizontal IIT for agricultural products in countries that joined the EU later.

Based on the aforementioned theoretical assumptions, this paper analyzes IIT of Serbia for agricultural products in the period between 2004 and 2018. Based on the movement of the GL index and the number of products characterized by horizontal and vertical IITs, the changes that occurred in the observed period are indicated. Also, the paper analyzes the dynamic application of GL indexes in a given period using OLS regression. 


\section{MATERIALS AND METHODS}

Intra-industrial trade is defined as the simultaneous export and import of products within the same industry sector. The extent of IIT can be measured by a Grubel-Lloyd index that relies on an index previously developed by Balassa (1966). The values of the Grubel-Lloyd Index (GLI) range from 0 to 1 and show the similarity of the exchange between the two countries (Grubel-Lloyd, 1975). The higher the index value, the higher is the IIT intensity. The index has a value of 0 when there are no products exported and imported within the same class $(\mathrm{GLi}=0 ; \mathrm{Xi}=0$ or $\mathrm{Mi}=0$ ), while the index is equal to 1 when the value of the exported and imported products within the same class is equal $(\mathrm{GLi}=1 ; \mathrm{Xi}=\mathrm{Mi})$. The GLI calculation formula is:

$$
G L I_{i . A B}=\frac{\left(X_{i}+M_{i}\right)-\left|X_{i}-M_{i}\right|}{\left(X_{i}+M_{i}\right)}
$$

$\mathrm{Xi}$ - the value of the exported product $\mathrm{i}$,

$\mathrm{Mi}$ - the value of the imported product $\mathrm{i}$.

According to Qasmi \& Fausti (2001), GLI values can be classified into four groups (as cited in Hoang, 2019, p.76).

Table 1. The classification of GLI values

\begin{tabular}{|c|c|c|}
\hline Class 1 & $0.00 \leq \mathrm{GLI} \leq 0.25$ & Strong inter-industry trade \\
\hline Class 2 & $0.25<\mathrm{GLI} \leq 0.50$ & Weak inter-industry trade \\
\hline Class 3 & $0.50<\mathrm{GLI} \leq 0.75$ & Weak intra-industry trade \\
\hline Class 4 & $0.75<\mathrm{GLI} \leq 1$ & Strong intra-industry trade \\
\hline
\end{tabular}

In order to compare results between countries and sectors, GLI can be aggregated at country and sector levels. The bilateral IIT index is calculated as the weighted average of the index (1) for all product classes i, with the weights of total trade with the product i relative to the total trade of all products. Country and sector IIT index is calculated by the formula:

$$
G L I_{i . A B}=\sum_{i}\left(\frac{\left(X_{i}+M_{i}\right)-\left|X_{i}-M_{i}\right|}{\left(X_{i}+M_{i}\right)}\right) *\left(\frac{\left(X_{i}+M_{i}\right)}{\sum_{i}\left(X_{i}+M_{i}\right)}\right)
$$

Grubel \& Lloyd (1971) state that IIT can be divided to horizontal and vertical one. Horizontal intra-industrial trade is defined as the simultaneous export and import of products classified in the same sector and at the same processing stage, while vertical IIT is defined as the simultaneous export and import of products classified in the same sector but at different stages of processing.

There are several options in the literature for separating horizontal and vertical IITs. Horizontal intra-industrial trade (HIIT) is defined as the 
exchange of products that are differentiated by different attributes not including quality, while vertical intra-industrial trade (VIIT) is the exchange of products characterized by different quality (Ekanayake, Veeramacheneni, \& Moslares, 2009, p. 30). The total IIT equals the sum of the horizontal and vertical IITs.

$$
G L I_{i}=H_{I I T}+\text { VIIT }_{i}
$$

Greenaway, Hine, \& Milner (1995) developed an approach of separating horizontal and vertical IITs using the relative units index (UV) of exports and imports. The Relative Units Index (UV) measures the average price of a product in a given group based on perfect information assumptions. According to Stiglitz (1987), even in cases of asymmetric information prices will be a reflection of quality. According to these assumptions, a product sold at a higher price is better than a product sold at a lower price. The formula used is as follows:

$$
1-\alpha \leq \frac{U V_{j}^{X}}{U V_{j}^{M}} \leq 1+\alpha
$$

In the above formula, $\mathrm{UV}$ denotes the value of the product unit, $\mathrm{X}$ is the export, $\mathrm{M}$ is the import of the product $\mathrm{j}$, and $\alpha=0.15$. According to Greenaway, Hine, \& Milner (1995), a product is horizontally differentiated if the unit export value compared to the unit import value is within the range of $15 \%$, otherwise it is a vertically differentiated product. Vertical IIT indicates significant differences in the quality of goods exported and imported. If the difference between unit values of exports and imports is lower than 0.85 , then the quality of the exported product is worse than the quality of the imported product and this represents a low-quality vertical IIT. If the difference between unit values of exports and imports is greater than 1.15 , then the quality of the product being exported is assumed to be better than the quality of the product being imported and this represents a high-quality vertical IIT.

The paper will apply OLS regression to look at the dynamic changes of GLI in the observed periods. This methodology has been applied in the works of Dalum, Laursen, \& Villumsen (1998) and Hoang (2019). The regression model can be represented by the formula:

$$
G L I_{j}^{t 2}=\alpha+\beta G L I_{j}^{t 2}+\varepsilon_{j}
$$

In the above formula, $\mathrm{t} 1$ represents the initial year, $\mathrm{t} 2$ the last year in the observed period, $\mathrm{j}$ is the observed commodity group, $\alpha$ is constant, $\beta$ is regression coefficient and $\varepsilon_{\mathrm{j}}$ is residual and is assumed to be normally and identically distributed according to the model assumption. In this formula $G L I_{j}^{t 2}$ is the index value in the last year for commodity group $\mathrm{j}$ and represents the dependent variable, while $G L I_{j}^{t 1}$ is the index value in the initial year for commodity group $\mathrm{j}$ and represents the independent variable. 
If the value of the regression coefficient $\beta=1$, the IIT pattern did not change in the observed period. In the case where $\beta>1$, the country with higher IIT value will increase the value of intra-industrial trade in products where it has already recorded a significant share of intra-industrial trade and increase the value of inter-industrial trade in products that have been characterized by inter-industrial trade. If $0<\beta<1$, it indicates that the existing pattern has changed, countries with high IIT value increase the value of interindustrial trade and vice versa, and if $\beta<0$ the positions are reversed compared to the initial period.

Dalum, Laursen, \& Villumsen (1998), as well as Hoang (2019) point out that regression analysis should show the extent of IIT changes over time and that $\beta>1$ does not represent a sufficient condition for IIT growth. The authors define the additional condition as:

$$
\frac{\delta_{t 2}}{\delta_{t 1}}=\left|\frac{\beta}{R}\right|
$$

In this formula $\delta_{\mathrm{t} 1}$ is a standard deviation during the first year, $\delta_{\mathrm{t} 2}$ is a standard deviation during the last year of the observed period, $\beta$ is the regression coefficient, $\mathrm{R}$ is the square root of the coefficient of determination. In the case where $\beta=R$ the GLI distribution is unchanged, if $\beta>R$ the GLI dispersion is increased and if $\beta<R$ there is a decrease in GLI dispersion.

The application of OLS regression in the aforementioned studies requires that IIT values have symmetrical, normal distributions and that extreme values are eliminated (Hoang, 2019). For this reason, it is necessary to transform the GL index into a TGL index by the formula:

$$
T G L I=2 G L I-1
$$

The TGLI value ranges between -1 and 1 , and zero represents a neutral point between inter-industrial and intra-industrial trade. In the calculation of OLS regression in this paper, GLI values will be replaced by the corresponding TGLI values.

The empirical data on exports and imports used in this paper are secondary data downloaded from the electronic database of the Statistical Bureau of the Republic of Serbia (RSZ, http://data.stat.gov.rs). The Statistical Bureau uses the fourth revision of the Standard International Trade Classification (SITC), data are presented by sections denoted by one digit (10 sections), divisions denoted by two digits (67 divisions), and groups representing the third level and denoted by three digits (262 groups). According to the United Nations Statistical Commission classification (2006) and the works of Durán Lima, Alvarez, \& Cracau (2016) and Hoang (2019), agricultural commodities analyzed in the paper include sections 0,1 , divisions 21 , 22, commodities 231; division 24, commodities 261, 263, 264, 265, 268, division 29, and sector 4. The Statistical Bureau of the Republic of Serbia also 
uses the Nomenclature of Foreign Trade Statistics (NFTS) to display data on exports and imports of products, which is based on the Standard International Trade Classification. The hierarchical structure of NFTS by digit positions has the same appearance as SITCs up to the position level (5-digit codes) and contains the same number of sections, divisions, groups, subgroups and positions (items). NFTS has 4,079 products and the structure of the code is as follows: sections (1-digit codes), divisions (2-digit codes), groups (3-digit codes), subgroups (4-digit codes), items (5-digit codes) and NFTS products (5+2 digit codes) (Statistical Bureau of the Republic of Serbia, 2007, p. 20).

The GLI value increases with the level of aggregation i.e. the index will have lower value when calculated at more detailed levels (United Nations, 2012, p. 20). For this reason, GLI value in this paper was calculated at the group level, with 60 agricultural groups included, and at the NFTS product level where 867 products were covered in the period from 2004 to 2018.

\section{RESULTS AND DISCUSSION}

In the observed period from 2004 to 2018, the value of Serbian agricultural exports increased fourfold, from USD 0.86 billion to USD 3.52 billion. Agricultural imports increased 2.3 times in the same period, from USD 0.94 billion to USD 2.17 billion. The foreign trade balance of agricultural products was positive during the analyzed period, except in the first year. In 2004, a deficit of USD 76.67 million was recorded. Since 2005, agricultural exports have outpaced imports, surplus growing from USD 131.76 million to USD 1.31 billion in 2018. During 2016, surplus reached USD 1.66 billion.

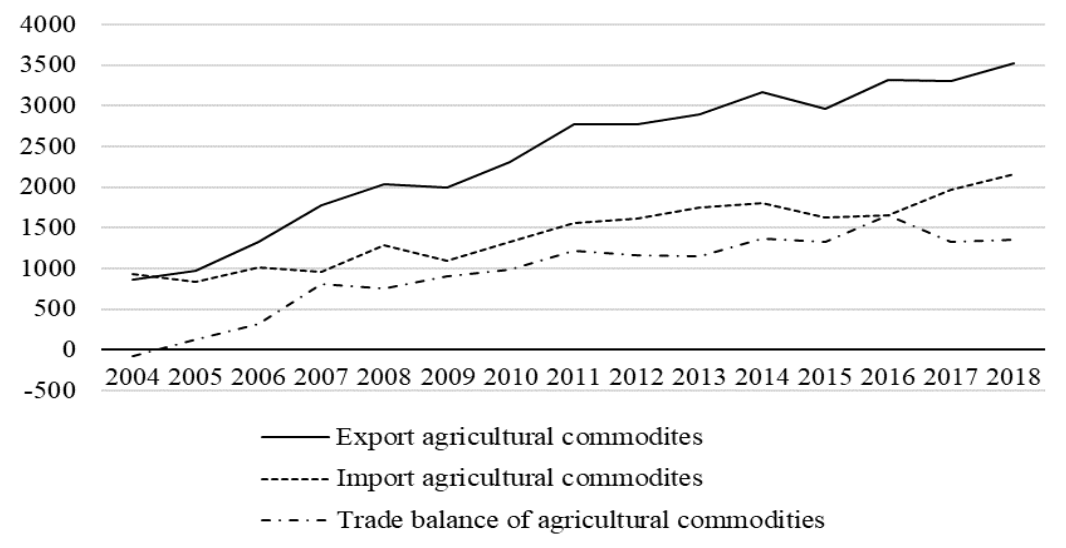

Figure 1. Value of export and import of agricultural products of Serbia 2004-2018. (In millions of USD) 


\section{Measuring the Intra-industrial Trade Using the GL Index}

In this paper we used GLI to measure IIT by agricultural products between Serbia and its foreign trade partners. Table 2 shows the commodity groups with the highest GLI value in 2018. Groups 001, 211, 098, 045, 073, 291, 431, 022 and 057 had a GLI value greater than 0.90 during 2018. Within these groups, GLI was highest for NFTS 0014910 (poultry domesticus, live, weighing more than 185g) 0.93, 2112900 (other raw hides and skins of bovine animals, including butts, bends and bellies) $0.98,0989900$ (Other food preparations) 0.99, 0989490 (food preparations of flour, meal, starch or malt extract, n.e.s.) 0.96, 0459900 (cereals, unmilled, n.e.s.) 0.97, 0733000 (other food preparations containing cocoa, in blocks or slabs, whether or not filled) 0.94, 2919300 (guts, bladders and stomachs of animals, whole and pieces thereof) 0.70, 4312200 (vegetable fats and oils and their fractions, hydrogenated, inter-esterified, re-esterified) $0.87,0221200$ (milk and cream, of a fat content, by weight, exceeding $1 \%$ but not exceeding 6\%) 0.96, 0579110 (melons and watermelons, fresh) 0.67.

However, interpreting GLI calls for caution. The GLI value increases with the level of aggregation, i.e. the index will have lower value when calculated at more detailed levels (United Nations, 2012, p. 20). For this reason, the GLI value in the paper was calculated at the group level and at the NSFT product level. This problem can be illustrated by the example of group 057 (Fruit and nuts (not including oilnuts), fresh or dried). There are 36 NSFT products within this group. The total GLI value at 057 group level is 0.918 , while individually, at the NSFT product level, some products are characterized by inter-industrial trade, and the GLI value ranges from only 0.008 to a maximum value of 0.651 .

The following table (Table 2) shows the GLI values for product groups where the value of exports was greater than USD 200 million during 2018, and includes the groups 058, 122, 044, 057, 041 and 081. The GLI value for these product groups ranged from 0.92 in group 057, which also belongs to the groups with the highest index value, to 0.008 in group 041, which is among the groups with the lowest index value. The last four groups represent products with the lowest GLI value in 2018, which include groups $041,043,422$ and 231 . Commodity group 041 is among the groups with the highest export value, so within this group a surplus is over USD 200 million. The surplus was also made with product group 043 and amounted to just over USD 14 million. In commodity groups 422 and 231, imports outstripped exports, so a significant deficit was observed in these groups. 
Table 2. Serbia's agricultural trade and intra-industry trade (top and selected) in 2018

\begin{tabular}{|c|c|c|c|c|c|}
\hline \multicolumn{2}{|c|}{ Code Commodity } & \multirow{2}{*}{$\begin{array}{c}\begin{array}{c}\text { Export } \\
\text { (million } \\
\text { USD) }\end{array} \\
44.16\end{array}$} & \multirow{2}{*}{$\begin{array}{c}\begin{array}{c}\text { Import } \\
\text { (million } \\
\text { USD) }\end{array} \\
43.71\end{array}$} & \multirow{2}{*}{$\begin{array}{r}\begin{array}{c}\text { Trade } \\
\text { balance }\end{array} \\
0.45\end{array}$} & \multirow{2}{*}{$\begin{array}{l}\text { GLI } \\
0.994\end{array}$} \\
\hline 001 & $\begin{array}{l}\text { Live animals other than animals of } \\
\text { division } 03\end{array}$ & & & & \\
\hline 211 & Hides and skins (except furskins), raw & 25.90 & 24.62 & 1.28 & 0.975 \\
\hline 098 & Edible products and preparations, n.e.s. & 175.50 & 163.54 & 11.96 & 0.965 \\
\hline 045 & $\begin{array}{l}\text { Cereals, unmilled } \\
\text { (other than wheat, rice, barley and maize) }\end{array}$ & 1.07 & 1.16 & -0.086 & 0.962 \\
\hline 073 & $\begin{array}{l}\text { Chocolate and other food preparations } \\
\text { containing cocoa, n.e.s. }\end{array}$ & 68.13 & 74.66 & -6.53 & 0.954 \\
\hline 291 & Cruide animal materials, n.e.s. & 6.62 & 5.80 & 0.82 & 0.934 \\
\hline 431 & Animal or vegetable fats and oils & 4.73 & 4.11 & 0.62 & 0.930 \\
\hline 022 & $\begin{array}{l}\text { Milk and cream and milk products, other } \\
\text { than butter or cheese }\end{array}$ & 63.74 & 54.10 & 9.64 & 0.918 \\
\hline 057 & $\begin{array}{l}\text { Fruit and nuts (not including oil nuts), } \\
\text { fresh or dried }\end{array}$ & 215.64 & 183.00 & 32.64 & 0.918 \\
\hline 058 & $\begin{array}{l}\text { Fruit, preserved, and fruit preparations } \\
\text { (excluding fruit juices) }\end{array}$ & 403.90 & 54.58 & 349.33 & 0.238 \\
\hline 122 & $\begin{array}{l}\text { Other meat and edible meat offal, fresh, } \\
\text { chilled or frozen }\end{array}$ & 278.87 & 138.11 & 140.75 & 0.662 \\
\hline 044 & $\begin{array}{l}\text { Maize (not including sweet corn), } \\
\text { unmilled }\end{array}$ & 266.75 & 18.49 & 248.26 & 0.130 \\
\hline 081 & $\begin{array}{l}\text { Feeding stuff for animals } \\
\text { (not including unmilled cereals) }\end{array}$ & 202.93 & 102.57 & 100.36 & 0.671 \\
\hline 041 & $\begin{array}{l}\text { Wheat (including spelt) and meslin, } \\
\text { unmilled }\end{array}$ & 210.38 & 0.84 & 209.54 & 0.008 \\
\hline 043 & Barley, unmilled & 14.45 & 0.08 & 14.38 & 0.011 \\
\hline 422 & $\begin{array}{l}\text { Fixed vegetable fats and oils, cruide, } \\
\text { refined or fractionated other than "soft" }\end{array}$ & 0.63 & 31.21 & -30.58 & 0.040 \\
\hline 231 & $\begin{array}{l}231 \text { - Natural rubber, balata, gutta- } \\
\text { oercha, guayule, chicle and similar } \\
\text { natural gums }\end{array}$ & 1.10 & 47.02 & -45.92 & 0.046 \\
\hline
\end{tabular}

Table 3 shows data on the number of NSFT groups and products broken down by IIT index value. The first group consists of products in which the IIT index values are between 0.50 and 0.75 and these products show weak intra-industry trade. The second group consists of products in which the value of the IIT index is between 0.75 and 1 and represents products with strong intra-industry trade. If viewed at the group level (3 digits), 33 groups were characterized by IIT 2018, while 27 were characterized by inter-industrial trade. Of these, 20 groups have shown strong IIT, while 13 groups have shown weak IIT. If observing based on the name of the NSFT product (7 digits) during 2018, the IIT was recorded in 
185 products, which represented $18.2 \%$ of the total number of products. In the analyzed period, at the group level, the total number of IITdominated groups ranged from 26 in 2009 to 35 in 2015. Viewed at the NSFT product level, the number of IIT products ranged from 98 in 2005 to 158 in 2018. According to the data presented in the table, there is a noticeable increase in the number of groups and products characterized by IIT.

Table 3. Number of NSFT groups and products characterized by ITT in 2004-2018 period

\begin{tabular}{ccccccccc}
\hline & \multicolumn{2}{c}{ Weak } & \multicolumn{2}{c}{ Strong } & \multicolumn{2}{c}{ Total } & \multicolumn{2}{c}{ Total } \\
\cline { 2 - 8 } & 3-digit & NSFT & 3-digit & NSFT & 3-digit & $(\%)$ & NSFT & $(\%)$ \\
\hline 2018 & 13 & 94 & 20 & 64 & 33 & 55.0 & 158 & 18.2 \\
2017 & 17 & 70 & 16 & 71 & 33 & 55.0 & 141 & 16.3 \\
2016 & 11 & 78 & 23 & 65 & 34 & 56.7 & 143 & 16.5 \\
2015 & 12 & 80 & 23 & 69 & 35 & 58.3 & 149 & 17.2 \\
2014 & 15 & 84 & 18 & 54 & 33 & 55.0 & 138 & 15.9 \\
2013 & 15 & 82 & 18 & 49 & 33 & 55.0 & 131 & 15.1 \\
2012 & 17 & 70 & 15 & 60 & 32 & 53.3 & 130 & 15.0 \\
2011 & 13 & 78 & 17 & 54 & 30 & 50.0 & 132 & 15.2 \\
2010 & 16 & 62 & 15 & 54 & 31 & 51.7 & 116 & 13.4 \\
2009 & 12 & 54 & 14 & 50 & 26 & 43.3 & 104 & 12.0 \\
2008 & 12 & 77 & 18 & 51 & 30 & 50.0 & 128 & 14.8 \\
2007 & 15 & 67 & 14 & 58 & 29 & 48.3 & 125 & 14.4 \\
2006 & 11 & 61 & 19 & 56 & 30 & 50.0 & 117 & 13.5 \\
2005 & 15 & 51 & 15 & 47 & 30 & 50.0 & 98 & 11.3 \\
2004 & 15 & 63 & 17 & 43 & 32 & 53.3 & 106 & 12.2 \\
\hline
\end{tabular}

Source: Author's calculation based on data by Statistical Bureau of the Republic of Serbia

\section{Horizontal and Vertical Intra-industrial Trade}

When analyzing GLI, it is important to consider the share of horizontal and vertical IITs in the total index value. Table 4 shows GLI values of agricultural products trade between Serbia and its foreign trade partners. As noted earlier, the index will have lower value if calculated at more detailed levels. For this reason, the GLI value was calculated at the group level (3 digits) and at the NSFT product level (7 digits) in the 2004-2018 period. Horizontal IIT (HIT) is an exchange of products of similar quality, i.e. products that are differentiated by other attributes excluding quality. Vertical IIT (VIIT) is an exchange of products of different quality. Vertical IIT indicates significant differences in the quality of goods exported and imported. If the difference between unit values of exports and imports is lower than 0.85 , then the quality of the exported product is worse than the quality of the imported product and it represents a low-quality vertical IIT. This IIT is shown in the table as VIIT1. If the difference between unit values of exports and imports is greater than 1.15 , 
it is assumed that the quality of the product being exported is better than the quality of the product being imported and this represents a high quality vertical IIT that is shown as VIIT2 in the table. Vertical IIT is equal to the sum of VIIT1 and VIIT2, while the total IIT is equal to the sum of horizontal (HIIT) and vertical (VIIT) intra-industrial trade.

In the observed period from 2004 to 2018, the total value of GLI for agricultural products, at group level (3 digits), ranged from 0.485 in 2004 to 0.590 in 2018. If the value is calculated at the NSFT product level (7 digits), the index value ranged from 0.248 in 2004 to 0.363 in 2018. In the observed period, there was an increase in the IIT index for agricultural products in Serbia. The lowest value of the IIT index was recorded in 2005 when it was 0.448 . Since 2013, the IIT index has been higher than 0.50 every year. Vertical IIT is more prevalent in the structure of the IIT index. The data presented in the table indicate that VIIT1 accounts for about $50 \%$ of the total value of the IIT index. As noted above, the vertical IIT indicates differences in the quality of the traded goods and VIIT1 indicates that the quality of the exported product is worse than the quality of the imported product. Within the IIT for agricultural products between Serbia and its partners, the export of products with lower prices is more prevalent, i.e. according to the assumptions of the model, those are of lower quality than imported products.

Table 4. GLI values for agricultural products of Serbia between 2004 and 2018

\begin{tabular}{llllllllllll}
\hline & \multicolumn{2}{c}{ HIIT } & \multicolumn{2}{c}{ VIIT1 } & \multicolumn{2}{c}{ VIIT2 } & \multicolumn{2}{c}{ VIIT } & \multicolumn{2}{c}{ GLI } \\
\cline { 2 - 12 } & 3-digit & NSFT & 3-digit & NSFT & 3-digit & NSFT & 3-digit & NSFT & 3 -digit & NSFT \\
\hline 2018 & 0.116 & 0.090 & 0.298 & 0.167 & 0.176 & 0.106 & 0.474 & 0.273 & 0.590 & 0.363 \\
2017 & 0.108 & 0.108 & 0.301 & 0.150 & 0.149 & 0.097 & 0.449 & 0.247 & 0.557 & 0.355 \\
2016 & 0.111 & 0.063 & 0.225 & 0.157 & 0.166 & 0.092 & 0.391 & 0.248 & 0.502 & 0.311 \\
2015 & 0.104 & 0.097 & 0.252 & 0.152 & 0.187 & 0.083 & 0.439 & 0.235 & 0.542 & 0.331 \\
2014 & 0.137 & 0.081 & 0.266 & 0.146 & 0.168 & 0.095 & 0.434 & 0.241 & 0.571 & 0.322 \\
2013 & 0.220 & 0.124 & 0.244 & 0.134 & 0.104 & 0.076 & 0.348 & 0.210 & 0.567 & 0.334 \\
2012 & 0.138 & 0.105 & 0.207 & 0.113 & 0.135 & 0.069 & 0.342 & 0.181 & 0.480 & 0.286 \\
2011 & 0.144 & 0.103 & 0.244 & 0.082 & 0.084 & 0.062 & 0.328 & 0.145 & 0.472 & 0.248 \\
2010 & 0.164 & 0.091 & 0.233 & 0.091 & 0.069 & 0.073 & 0.301 & 0.164 & 0.465 & 0.255 \\
2009 & 0.127 & 0.055 & 0.236 & 0.108 & 0.091 & 0.076 & 0.327 & 0.184 & 0.453 & 0.239 \\
2008 & 0.089 & 0.059 & 0.272 & 0.129 & 0.122 & 0.072 & 0.394 & 0.200 & 0.484 & 0.260 \\
2007 & 0.086 & 0.089 & 0.265 & 0.093 & 0.128 & 0.061 & 0.394 & 0.153 & 0.479 & 0.242 \\
2006 & 0.049 & 0.087 & 0.280 & 0.106 & 0.156 & 0.068 & 0.436 & 0.174 & 0.486 & 0.261 \\
2005 & 0.074 & 0.055 & 0.232 & 0.100 & 0.142 & 0.075 & 0.374 & 0.175 & 0.448 & 0.230 \\
2004 & 0.092 & 0.053 & 0.213 & 0.123 & 0.180 & 0.071 & 0.393 & 0.195 & 0.485 & 0.248 \\
\hline Source: Author's calculation based on data by Statistical Bureau of the Republic of Serbia
\end{tabular}

Based on available data at the NSFT product level, the number of products characterized by horizontal and vertical IIT, as well as by inter- 
industrial trade was calculated. The results obtained are shown in Table 5. Out of the total number of products, products where quantity data were not available were excluded. During the observed period, there was an increase in products characterized by horizontal IIT - from 81 in 2004 to 122 in 2018. In the same period, the number of products for which a difference between unit values of exports and imports is less than 0.85 (VIIT1) ranged from 166 in 2010 to 205 in 2016. The number of products where the difference between unit values of exports and imports exceeds 1.15 (VIIT2) increased significantly in the observed period, from 117 in 2004 to 210 in 2017. On the other hand, the number of products with recorded intra-industry trade and without any trade was declining. The results shown in Table 5 point that during 2018, vertical IIT was recorded in 372 products, while horizontal IIT was recorded in 122 products. These results indicate that in Serbia, IIT in agricultural products most often includes products of different prices and quality.

Table 5. Number of NSFT products according to the characteristic trade level

\begin{tabular}{cccccc}
\hline year & HIIT & VIIT1 & VIIT2 & $\begin{array}{c}\text { Inter-industry } \\
\text { trade }\end{array}$ & non \\
\hline 2018 & 122 & 183 & 189 & 135 & 39 \\
2017 & 107 & 189 & 210 & 118 & 45 \\
2016 & 111 & 205 & 184 & 131 & 44 \\
2015 & 124 & 171 & 193 & 139 & 46 \\
2014 & 114 & 184 & 196 & 120 & 50 \\
2013 & 127 & 168 & 185 & 152 & 42 \\
2012 & 121 & 180 & 182 & 131 & 57 \\
2011 & 121 & 178 & 166 & 143 & 63 \\
2010 & 108 & 166 & 174 & 160 & 60 \\
2009 & 90 & 190 & 167 & 154 & 70 \\
2008 & 93 & 200 & 162 & 160 & 60 \\
2007 & 94 & 187 & 151 & 178 & 63 \\
2006 & 84 & 199 & 173 & 156 & 63 \\
2005 & 77 & 176 & 139 & 199 & 80 \\
2004 & 81 & 181 & 117 & 179 & 113 \\
\hline S & & & & & \\
& & & & \\
Suthor's calculation based on data by Statistical Bureau of the Republic of Serbia
\end{tabular}

\section{Dynamical Changes of GLI}

In several groups of agricultural products there were significant changes in GLI over the observed period. Groups 061, 091, 122, and 244, which at the beginning of the period were characterized by strong interindustrial trade, during 2018 represented groups of products with weak IIT. The groups 025 and 211, classified as weak inter-industrial trade by GLI, became strong IIT groups. The most dynamic changes occurred in the 041 and 245 product groups, which changed from strong IIT at the 
beginning of the period, to the strong inter-industrial trade at the end of the observed period.

Table 6. Results of OLS regression

\begin{tabular}{ccccccccc}
\hline \multicolumn{3}{c}{$2004-2011$} & \multicolumn{3}{c}{$2012-2018$} & \multicolumn{3}{c}{$2004-2018$} \\
\hline$\beta$ & $\mathrm{R}$ & $\beta / \mathrm{R}$ & $\beta$ & $\mathrm{R}$ & $\beta / \mathrm{R}$ & $\beta$ & $\mathrm{R}$ & $\beta / \mathrm{R}$ \\
\hline 0.54 & 0.56 & 0.96 & 0.72 & 0.73 & 0.98 & 0.53 & 0.56 & 0.95 \\
\hline
\end{tabular}

The results of the applied methodology and OLS regression for the three periods are shown in Table 6 . In all periods $0<\beta<1,0<\mathrm{R}<1$ while $\beta / R<1$. According to the explained methodology, the obtained results indicate that certain changes occur and that the IIT pattern changes over time, i.e. high-value IIT product groups increase the value of interindustrial trade and vice versa. Also, since $\beta<\mathrm{R}$, the obtained result indicates that GLI dispersion decreased during the observed period. The values of the coefficients $\beta$ and $\mathrm{R}$ indicate that changes occur gradually and that there are no sudden and fundamental changes. Changes were minimal, especially in 2012-2018 period.

\section{CONCLUSION}

Agricultural products represent an important product group in the foreign trade of Serbia. In the $2004-2018$ period, it participated on average with $21.7 \%$ in total export and $7.9 \%$ in total import. The average growth of agricultural products export in this period was $11 \%$, slightly lower than the average annual growth of total exports of the Serbian economy, which amounted to $14 \%$. On the other hand, the import of agricultural products grew at an average annual rate of $7 \%$, while total import grew at an average annual rate of $8 \%$. The balance of foreign trade of agricultural products in the observed period was positive, except in the first year when import of agricultural products was higher than export.

The paper analyzes the values of GLI for agricultural products at group level (3 digits) and NSFT product level (7 digits) between Serbia and its foreign trade partners. The index value ranged from 0.448 to 0.590 (3 digits). When calculating the value at the NSFT product level ( 7 digits), the index value ranged from 0.248 in 2004 to 0.363 in 2018. As GLI increases with the level of aggregation, data used in the paper were at the group level and the NSFT product level. From the results presented, it can be concluded that the aggregation problem is especially emphasized in group 057. Some of the NSFT products within this group are characterized by IIT, with the highest GLI value being 0.651. A more detailed analysis indicates that this group is more characterized by inter-industrial trade, although GLI values at the group level indicated a strong IIT. Not- 
withstanding the above examples, the overall GLI results at the group level and NSFT product level indicate that the pattern of trade is changing and that IIT is becoming more and more represented in foreign trade in agricultural products in Serbia.

The data presented in the paper indicate that IIT over time gains importance in the exchange of agricultural products between Serbia and other countries. The number of products for which simultaneous export and import is registered increases from year to year, while the number of products with characteristic inter-industrial trade is decreasing. The obtained results show increase of HIIT, i.e. the exchange of products of similar quality and price. During the observed period, the share of NSFT products characterized by HIIT increased from $11.8 \%$ to $17.8 \%$. Also, a significant growth was achieved in VIIT. The share of NSFT products characterized by VIIT1 did not change significantly, so the share of these products in 2004 was $26.3 \%$, while in 2018 it was $26.6 \%$. The most significant growth was achieved in NSFT products characterized by VIIT2, because the share of these products increased from $17.0 \%$ at the beginning of the observed period, to $27.5 \%$ in 2018 .

The largest part of the IIT of Serbia, measured by the GL index, represents the vertical IIT. According to the obtained results, the lowquality vertical IIT (VIIT1) makes about $50 \%$ of the total value of the IIT index. According to theoretical assumptions, vertical trade is characteristic of the exchange of goods of different quality, and VIIT1 indicates that the quality of an exported product is worse than the quality of the same imported product. Based on the obtained results, it can be concluded that the IIT of agricultural products between Serbia and its foreign partners is dominated by the export of lower-priced products, i.e. those that are, according to the model assumptions, of the lower quality, and the import of the same products but of higher quality. Similar results in the analysis of the surrounding countries and countries that later joined the EU were obtained by Jámbor (2015 and 2011) and Fertő (2015). Although VIIT1 makes up over $50 \%$ of the value of the GL index, the number of products within VIIT2 has increased significantly. This indicates the increase of the number of agricultural products in which the quality of the exported product is better than the quality of imported products. However, the value of foreign trade in these products in total foreign trade is significantly lower than the value of foreign trade in products characterized by VIIT1, which explains the higher share of VIIT1 in total IIT.

The analysis of the dynamic changes using OLS regression shows that there is a change in the pattern of IIT over time and that certain groups of products that were characterized by inter-industrial trade increase the value of IIT and vice versa. However, the ratios of the coefficients $\beta$ and $\mathrm{R}$ show that changes occur gradually over a longer period of time and that there are no sudden changes in the pattern of trade and the 
structure of IIT, which was especially characteristic for the period between 2012 and 2018.

This paper is the starting point for the analysis of IIT of agricultural products in Serbia. In further research and IIT analysis, it would be important to analyze individual data for the countries with which the exchange was made. Further analysis would also require identifying the reasons for the changes, the reasons for imports of agricultural products of similar quality, and the potential problems encountered by domestic farmers in the case of imports of agricultural products of similar quality. Empirical data presented in the paper can be used for further analysis and the definition of measures and policies that would help to improve the quality of exported agricultural products in comparison to the imported ones and to improve the competitiveness of the agricultural sector of Serbia.

Acknowledgment: This paper is the result of research on obligations under the Agreement on the Implementation and Financing of the Scientific Research in 2020 (registration number 451-03-68 / 2020-14 / 200100) concluded between the Ministry of Education, Science and Technological Development of the Republic of Serbia and the Faculty of Economics, University of Niš.

\section{REFERENCES}

Balassa, B. (1966). Tariff Reductions and Trade in Manufacturers among the Industrial Countries. The American Economic Review, 56(3), 466-473.

Ćuzović, S. (2009). Trgovina: principi, struktura, razvoj. Niš: Ekonomski fakultet, Univerzitet u Nišu. [Ćuzović, S. (2009). Trade: Principles, Structure, Development. Niš: Faculty of Economics, University of Niš.]

Dalum, B., Laursen, K., \& Villumsen, G. (1998). Structural Change in OECD Export Specialisation Patterns: de-specialisation and 'stickiness'. International Review of Applied Economics, 12(3), 423-443. doi:doi:10.1080/02692179800000017

Durán Lima, J. E., Alvarez, M., \& Cracau, D. (2016). Manual on foreign trade and trade policy: Basics, classifications and indicators of trade patterns and trade dynamics. Project Document LC/W.430. Economic Commission for Latin America and the Caribbean (ECLAC).

Ekanayake, E. M., Veeramacheneni, B., \& Moslares, C. (2009). Vertical and Horizontal Intra-Industry Trade Beetween the U.S. and Nafta Partners. Revista de Analisis Economico - Economic Analysis Review, 24(1), 21-42.

Fertő, I. (2015). Horizontal intra-industry trade in agri-food products in the enlarged European Union. Studies in Agricultural Economics, 117(2), 1-7. doi:10.22004/ ag.econ. 208883

Frankel, H. (1943). Industrialization of Agricultural Countries and the Possibilities of a New International Division of Labour. Economic Journal, 188-201.

Greenaway, D., Hine, R., \& Milner, C. (1995). Vertical and Horizontal Intra-Industry Trade: A Cross Industry Analysis for the United Kingdom. The Economic Journal, 105(433), 1505-1518. doi:https://doi.org/10.2307/2235113

Grubel, H., \& Lloyd, P. (1975). Intra-Industry Trade: The Theory and Measurement of International Trade in Differentiated Products. London: Macmillan Press.

Grubel, H., \& Lloyd, P. J. (1971). The Empirical Measurement of Intra- Industry Trade. The Economic Record, 47(120), 494-517. 
Hoang, V. (2019). The Dynamics of Agricultural Intra-Industry Trade: A Comprehensive Case Study in Vietnam. Structural Change and Economic Dynamics, 49, 74-82.

Jámbor, A. (2010). Intra-industry trade of Hungarian agricultural products and the EUaccession. Studies in Agricultural Economics, 111, 1-19. doi:10.22004/ag.econ. 59048

Jámbor, A. (2015). Country- and industry-specific determinants of intra-industry trade in agri-food products in the Visegrad countries. Studies in Agricultural Economics, 117(2), 1-9. doi:http://dx.doi.org/10.7896/j.1514

Kol, J., \& Tharakan, P. K. (1989). Intra-Industry Trade, Traditional Trade Theory and its Extensions. In J. Kol, \& P. K. Tharakan (Eds.), Intra-Industry Trade: Theory, Evidence and Extensions (pp. 1-14). London: Palgrave Macmillan.

Lloyd, P., \& Lee, H. (2002). Frontiers of Research in Intra-Industry Trade. (P. Lloyd, \& H. Lee, Eds.) Palgrave Macmillan UK. doi:10.1057/9780230285989

Qasmi, B. A., \& Fausti, S. W. (1999). Nafta Intra Industry Trade In Agricultural Food Products. 1999 Annual Meeting, July 11-14, 1999, (pp. 255-271). Fargo, ND: Western Agricultural Economics Association. doi:10.22004/ag.econ.35689

Republički zavod za statistiku. (2007). Metodologija statistike spoljne trgovine. Statistical methodology in foreign trade. Metodologije i standardi. Beograd: Republički zavod za statistiku. [Statistical Bureau of the Republic of Serbia (2007). Statistical methodology in foreign trade. Methodologies and standards. Belgrade: Statistical Bureau of the Republic of Serbia].

Stiglitz, J. E. (1987). The Causes and Consequences of The Dependence of Quality on Price. Journal of Economic Literature, 25(1), 1-48.

United Nations. (2012). A Practical Guide to Trade Policy Analysis. United Nations Conference on Trade and Development.

United Nations Statistical Commission. (2006). Standard International Trade Classification: Revision 4. Statistical Papers, Series M(No. 34/Rev. 4). New York: United Nations.

Verdoorn P.J. (1960). The Intra-Bloc Trade of Benelux. In: Robinson E.A.G. (Ed.): Economic Consequences of the Size of Nations (291-332). London: Palgrave Macmillan.

\title{
ИНТРАИНДУСТРИЈСКА ТРГОВИНА ПОЉОПРИВРЕДНИМ ПРОИЗВОДИМА У СРБИЈИ
}

\author{
Ђорђе Ћузовић ${ }^{1}$, Светлана Соколов-Младеновић ${ }^{2}$ \\ ${ }^{1}$ Висока пословна школа струковних студија, Нови Сад, Србија \\ ${ }^{2}$ Универзитет у Нишу, Економски факултет, Ниш, Србија
}

\section{Резиме}

Услед пада транспортних трошкова, либерализације међународне трговине, стварања економских интеграција, у другој половини 20. века долази до интензивирања међународних трговинских токова. Упоредо са растом размене производа различитих сектора привреде, долази и до раста размене производа истих сектора привреде. Најчешћа дефиниција интраиндустријске трговине је да она представља истовремени извоз и увоз сличних производа или услуга од стране исте државе.

Прве студије које су се бавиле феноменом интраиндустријске трговине (ИИТ) спроведене су шездесетих година 20. века (Verdoorn, 1960, Balassa, 1966), а након то- 
га објављена је обимна литература која анализира ову област. Велика пажња истраживача посвећена је изучавању ИИТ, јер је у супротности са традиционалним теоријама међународне трговине.

Поред индустријских производа, где је ИИТ и прво уочена, ИИТ постаје све чешћа и код пољопривредних и прехрамбених производа. Према подацима Републичког завода за статистику, учешће пољопривреде у БДП-у 2018. године износило je $7 \%$, док је извоз пољопривредних и прехрамбених производа чинио $18,3 \%$ вредности укупног извоза.

У раду је анализирана интраиндустријска трговина пољопривредним производима Србије и њених спољнотрговинских партнера у периоду од 2004. до 2018. године. Обим ИИТ у раду мерен је Грубел-Лојдовим индексом (Grubel-Lloyd, 1975), који се ослања на индекс који је раније развио Баласа (Balassa 1966). Вредности Грубел-Лојдовог индекса (GLI) крећу се од 0 до 1 и показују сличност размене две земље. Што је вредност индекса већа, већи је интензитет ИИТ. Индекс има вредност 0 када нема производа у оквиру исте класе који су извезени и увезени $(\mathrm{GLi}=0 ; \mathrm{Xi}=$ 0 ili $\mathrm{Mi}=0)$, док је индекс једнак 1 када је вредност извезених и увезених производа у оквиру исте класе једнака $(\mathrm{GLi}=1 ; \mathrm{Xi}=\mathrm{Mi})$. Због осетљивости индекса на ниво агрегације, вредност GLI је у раду рачуната на нивоу група и обухваћено је 60 пољопривредних група и на нивоу производа НССТ, где је обухваћено 867 производа у периоду од 2004. до 2018. године.

У посматраном периоду од 2004. до 2018. године, укупна вредност GLI пољопривредним производима, на нивоу група (3 цифре), кретала се од 0,485 , колико је износила 2004. године, па до 0,590 , колико је износила 2018. године. Уколико се вредност рачуна на нивоу производа НССТ (7 цифара), вредност индекса се кретала од 0,248 (у 2004. години) до 0,363 (у 2018. години).

Једна од карактеристика ИИТ пољопривредним производима у Србији је да је вертикална ИИТ заступљенија од хоризонталне ИИТ. Према добијеним резултатима, ВИИТ1 чини око 50\% укупне вредности индекса ИИТ. Према теоријским претпоставкама, вертикална трговина је карактеристична за размену роба различитог квалитета, а ВИИТ1 указује на то да је квалитет извозног производа слабији од квалитета увозног производа. Добијени резултати указују на то да у оквиру ИИТ пољопривредним производима Србије и њених партнера доминира извоз производа који имају ниже цене, тј. који су према претпоставкама модела слабијег квалитета.

Анализа динамичких промена применом ОЛС регресије показује да долази до промене обрасца ИИТ током времена. Према добијеним резултатима у периоду од 2004. до 2018. године, дошло је до смањења дисперзије GLI. Ипак, односи коефицијената $\beta$ и R показују да се промене у дужем временском периоду дешавају постепено и да нема наглих промена у обрасцу трговине и структури ИИТ. 